\title{
Trump: the negative uprise in Political Humor
}

\author{
Constantino Pereira Martins \\ FCSH- Nova University of Lisbon/ IEF - University of Coimbra /FCT Foundation \\ E-mail: constantinomar@gmail.com
}

\begin{abstract}
The 2016 campaign for the U.S. Presidency revealed, and confirmed, the new turn that the role of emotions play in the present political landscape across the globe. The big happening wasn't so much the relation between emotions and politics but more the scale and overwhelming strategic use of negative emotions in the political debate. Understanding emotions as underlying the rationality process, involves cognitive and strategic consequences and, to the limit, their influence in decision-making. Politics always operated in this ambivalence and political campaign strategists are particularly concerned with the timing where these operators must be more efficiently communicated. This has been a well-known recipe used in mild doses and with the focus on a balanced performance. The political campaign for the U.S. Presidency in 2016 seems to follow this general rule but also introduces a particular novelty: the ex-

sibility of covering all the contours of the problem at hand we will focus on the Trump campaign, since it was one of transgression, which made use of aggressive tactics regarding common sense ideas, political correctness and taboo issues. Regarding Trump's campaign as one of management of the provocateur factor, we will try to present the two main emotional ingredients that supported a campaign established in an efficient use of timing, media and boredom. The first emotion in analysis will be fear. This implies exploiting one of the most powerful tools in the political emotion pallet. The main derivatives could be aggression, violence, hate and resentment. The second emotion in focus will be contempt. This means the discussion of ad hominem attacks and the power of humor through scorn and mockery. In general, our goal will be to map the negative up rise in political emotionality and its strategic use in the campaign.
\end{abstract} tensive use of negativity in the debate. In the impos-

Keywords: humor; emotions; political campaign; political communication; political humor; Trump.

Tenho duas armas para lutar contra o desespero, a tristeza e até a morte: o riso a cavalo e o galope do sonho. É com isso que enfrento essa dura e fascinante tarefa de viver.

I have two weapons to fight against despair, sadness and even death: laughter on horseback and the gallop of the dream. This is how I face that hard and fascinating task of living.

Ariano Suassuna

Data de submissão: 2018-02-28. Data de aprovação: 2018-04-12.

A Revista Estudos em Comunicação é financiada por Fundos FEDER através do Programa Operacional Factores de Competitividade - COMPETE e por Fundos Nacionais através da FCT - Fundação para a Ciência e a Tecnologia no âmbito do projeto Comunicação, Filosofia e Humanidades (LabCom.IFP) UID/CCI/00661/2013.
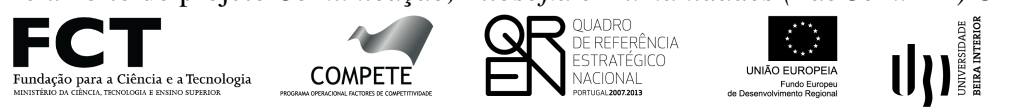


\section{GENERAL CONSIDERATIONS ON THE STUDY-CASE}

THE 2016 campaign for the U.S. Presidency revealed, and confirmed, the new turn in the role 1 that emotions play in the present political landscape across the globe. The big shift wasn't so much in the relation between emotions and politics, as in the scale and overwhelming strategic use of negative emotions in political debate. In general, the role of emotions emerges in politics as an expression and result of the combat that is characteristic of the political process. The question of empathy and adherence to a certain political perspective were always present in rhetorical reflections, alongside the part played by the mobilization of passions. Understanding emotions as underpinning the rationality process involves recognising their cognitive and strategic consequences, and the extent of their influence on decision-making. Politics always operated in this zone of ambivalence (reason-emotion), and political campaign strategists are particularly concerned with calculating the best timing for maximum communicative efficiency. This has become established as a well-known recipe used in mild doses and with the focus on a balanced performance. The political campaign for the U.S. Presidency in 2016 seems to follow this general rule but also introduces a particular novelty: the extensive use of negativity in the debate. Acknowledging the impossibility of covering all the contours of the problem at hand, I will here focus on the Trump campaign, since it was one of transgression that made use of aggressive tactics attacking common sense ideas, political correctness, and taboo issues. Regarding Trump's campaign as one of management of the provocateur factor through the embodiment of the infant terrible persona, I will try to present the two main emotional ingredients that supported a campaign established on the basis of efficient coordination of timing, media and boredom. The first emotion I will analyse is fear. The use of fear implies exploiting one of the most powerful tools in the political emotional palette. Its main derivatives could be aggression, violence, hate and resentment. The second emotion in focus will be contempt. This means the discussion of ad hominem attacks and the power of humor wielded through scorn and mockery. Is the affective power also anchored in effective humor, or is it effective power guided by affective humor?

In general, my goal will be to map the rise in negative political emotionality and its strategic use in the campaign. The argumentative analysis of the political-performance discourse will occur through a double effort of decomposition and deconstruction, trying to understand how laughter brings a certain flavor of anarchical distress into play and how it affects political perceptions and actions. But why is subversive humor so close to Philosophy? This is because it implies a phenomenological strategy of distance, and puts in suspension the natural and habitual understanding of life - just as philosophy is part of an interruption. In this sense it subverts because it does not collaborate with the habitual becoming of things in general. This process depends on its functional value as a strategic possibility, which stems from playing with the mechanisms and devices of laughter. This is where its proximity to politico-emotional territory lies. The role of humor in rhetoric bears relation to the connection between power and subversion (or interruption), and this reminds us of the jester figure in old monarchic times where the fool or the clown ${ }^{1}$ points to

1. Cf: Kasper, K., O jogo dos Clowns, Revista Nada n 17, 2013; Král, P., Le Burlesque, Éditions Ramsay, of California Press; Moore, M.P., "The Quayle Quagmire": Political Campaigns in the Poetic Form of Burlesque, Western Journal of Communication, 56 (Spring 1992), 108-124. 
this long tradition of irruption of the absurd or the indication of a specific or generic perplexity. The child that points to the naked king is already a laughing finger. ${ }^{2}$ But not only to the king of course. The argument that I would like to propose here is that Mr. Trump, now President Trump, is the incarnation of that historic figure - resulting in the absurd realization, by being elected, of the anti-king that takes power, the anti-king-king. This sort of stand up and subversive humor of the infant terrible ranting against political-correctness means a victory based on making full use of Schopenhauer's ${ }^{3}$ theory on always being right, and on the contemporary manifestation of Machiavelli's Prince. Understanding the anatomy of the "real world" 4 means to understand the ways of getting into power through words and votes in modern democracies, to reveal the versatility of the political actor in the U.S. elections, where the Trump campaign showed and exemplified the risks of populism and the dangers of transforming a political campaign into a circus. The gap between promise and delivery demonstrates the paradoxes implicit in the invocation of the "bs factor", revealing a desert of ideas that is to a degree determined by the tone (boring $v s$. appealing), and the trend of treating politics as part of the entertainment business (circus maximus), as well as showing the fragility of the political-correctness line of action.

In fact, Trump is not only the master of a mass media culture of scandals supported by a theory of shock ${ }^{5}$ and surprise, but also supported by an informal logic rooting the campaign in the old concepts of psi war and propaganda. ${ }^{6}$ In light of the impossibility of constituting a political epistemology, the analysis of political rhetoric as an emotions-based discourse has opened up a field of research that is now growing in some Universities and on some Media platforms. The main questions that are in place involving politics, rhetoric and emotion or humor, could be summarized in terms of: decision-making and motivation, ${ }^{7}$ and the processes of cognition and perception (regarding judgments and social constructions). ${ }^{8}$ If we had to condense this in a preliminary equation, it would be: Emotion-cognition-perception-action. I will come back to this later. Putting this conceptual structure into context, we could say that Mr. Trump gained from the fortunate coincidence

2. Cf. Smith, C. ,Voth, B., The Role of Humor in Political Argument: How 'strategery' and 'lockboxes' Changed a Political Campaign, 2002.

3. A practical philosophical exercise, and our main theoretical foundation for understanding the rhetorical battleground of the 2016 US Presidency campaign, would be to review the Trump's candidacy campaign according to the Schopenhaurian premisses on the art of insult, controversy and always being right. Cf. Schopenhauer, A., The art of controversy, the art of insult, the art of always being right.

4. Referring to the Machiavellian perspective suggests that old dilemma: do the ends justify the means? Cruelty, or just common sense?

5. This relates to political correctness and the descrediting of contemporary democracies. A shock theory entails a continuous state of provocation and pushing the boundaries. The subtle and shocking art of manipulation playing with the limits could, paradoxically, be totally exposed. This is particularly true regarding the relationship between politics and the media.

6. The new political marketing and communication strategies make full use of big data and other conceptual tools that changed the rules of the game towards Cyberpolitics. Amongst other strategies, it brings into play the ridiculous exemplary notion of post-truth.

7. A subsumed relation, with regard to the role of emotions in decisions and choices, in the passage from emotion to action. Cf: Solomon, R. (Ed.), What is an emotion?, Oxford University Press, 2003.

8. The power of association of ideas, overlapping concepts and images, which plant and grow thoughts in the back of your mind. Cf: Inception, 2010, Dir: Christopher Nolan. 
of running for President within a time frame that could be described as Affective Capitalism. ${ }^{9}$ This means that he had a long-term plan in the context of a short-time-living philosophy where everything is ephemeral. This is the context that enabled him to slowly build his own social capital, ${ }^{10}$ joining memory and familiarity, proximity and recognition. Affective Capitalism in Politics means, for the running candidate, a radical jump from being an apprentice ${ }^{11}$ into the role of master of manipulation. Trump's affective-effective politics of collective emotionality brings to light the formidable spiral of the present times: the boredom ${ }^{12}$ within the boredom is nausea, vertigo. No way out. What does boredom push us collectively, as a society, as a civilization, to? The emptiness of boredom demands entertainment. From media (maximus) circus to the political arena, the jester wannabe king, the ultimate joker, uses all his social capital to transform TV screen familiarity (habit, and ritual) into political credibility. This is an old trick and strategy, well known in mediaoriented societies, that can sometimes defy logic and reason and certainly runs along opposite lines to Rawls' principle of reasonability. ${ }^{13}$ It reinforces our hermeneutic hypothesis of the rise of the negative political emotion process. With the emotional appeal also comes the construction of a political image, ${ }^{14}$ and this invokes the unfathomable question of charisma, a clear example of affection, and the play of dispositions and emotions in the personalization process of politics. ${ }^{15}$ Of course, in Mr. Trump's case, the question of egocentrism and narcissism ${ }^{16}$ reached levels unprecedented in the democratic contemporary world, accompanied by the illusion and mirage of confusing a strong man with an aggressive man, cultivated by his offensive strategy.

The magical thought that presides over the rhetoric of this political illusionist ${ }^{17}$ brings with it uncertainty and unpredictability and, in this sense, is on one hand a huge risk and, on the other, an antidote to boredom, this profound cancer of the societies of the 21 st century. Trump rhetoric is the political business show in its purest form.

9. For further discussion of this concept, see the work of Bernard Stiegler, for example: Decadence of Industrial Democracies (Polity Press, 2011).

10. For more on this, see: The apprentice- D. Trump; Guy Debord- Homo Spectator - Marie-José Mondzain.

11. The celebrity apprentice, mastering the art of the deal, manipulates the media circus as if it were Nero's fire, reminding one of Nietzsche on stage on a stand-up comedy night: laughing like a hammer. The iconoclasm and the status of images is a task for others to think. He is the center of attention.

12. Tedium and boredom as the great epidemic outbreak of the $21^{\text {st }}$ Century.

13. Cf Reasonable doubt principle, reasonableness. Rawls, J., Political liberalism, p. 48, Columbia University Press, 1995.

14. Personal image and the image that is contained in concepts and ideas. In relation to the expression of ideas, it could be interesting to think about a politics of expression.

15. Ben-Ze'ev, A., The Subtlety of Emotions, Ed. Massachusetts Institute of Technology, 2000; Manstead, A. ,Frijda, N., Fischer ((Ed.), A., Feelings and Emotions, Cambridge University Press, 2004.

16. Though it is impossible to expand upon the concept here, it must be noted that are differences regarding the degree and types of narcissism. Perhaps political psychology could expand more on the peacock syndrome in a losersand-winners closed logic.

17. In the most pragmatist approach to Politics, what does Democracy mean? It could be suggested that this would mean: managing the momentum of voting. 
Or, in the words of Mel Brooks: "It's good to be the king". Skipping a deeper psychoanalytic analysis of the relation between narcissus and the mirror, ${ }^{18}$ we could say that the humorous-oneman-show in question here is a cold humor, or a sort of show by a cold humorist who does not realize the magnitude of his humor or simply feigns seriousness to reinforce his comedy. It is not really sarcasm, nor plain irony, but it may be a sort of dry humor that mixes terror with greed. I would suggest that the perfect symbolic image for this sort of parody is Bill 'The Butcher' from Scorsese's film, "Gangs of New York". In a certain sense, the whole film anticipates the general peacock character-features and the whole presidential debate, in the sequence which shows the arrival of the Irish immigrants by boat. ${ }^{19}$ This coldness may be related to one of the main processes crucial to the political game: fear.

\section{GENERAL CONSIDERATIONS ON FEAR}

Mr. Trump's strategy was very effective during the campaign and makes use of a main ingredient that is of central concern in political anthropology: this is one of politics' most classical devices and mechanisms - using fear as one of the great operators, as Hobbes so vividly underlines. It is human nature, or its projection, ${ }^{20}$ that achieves a legitimizing contract which, in Hobbes's view, confronts a state of nature, i.e., a state of fear or death. For Hobbes (unlike Rousseau), the state of nature, as a state of fear ${ }^{21}$ inherent to the human condition, stands in contrast to the contract, which is a space free from nature and its hostility to political formation. The political, as an anthropological contractual fiction, is founded on the will and desire for security. ${ }^{22}$ The State promotes a deletion of a state of nature, providing a guarantee of reason to remedy a natural failing. We have entered circularity in the nature of the contract: the fear of death demands security, security is the political response to fear of death and its own legitimation. There is a quasi-pathology, in the desire for security based in fear. Homo homini lupus. So, fear as an engine promotes the felt need for safety and security and in most cases, even historically, people are open to sacrificing freedom and other crucial values for safety. On the other hand, the premises of the political contract regulating the game may also be transformed for different contexts, meaning that fear can also be used in (imploded) ${ }^{23}$ derivatives like anxiety, anticipation, etc - this is the camouflaged use of fear found in the political battle ground. If we expand this mechanism ad infinitum we could find more serious explosive emotions like anger, rage, etc. Understanding Politics as the art of management of uncertainty and fear could bring some clarity to the U.S. Presidency campaign,

18. I am unable to cover this in great depth here, but would like to draw attention to the relevance of Umberto Eco's discussion on mirrors ('Mirrors', in Semiotics and the Philosophy of Language (Bloomington: Indiana University Press, 1984), pp. 202-226).

19. www.youtube.com/watch?v=4jcvpEO19ug; Gangs of New York, 2002, Dir. Martin Scorcese.

20. From pessimism to scepticism Cf: Strauss., L., Natural right and history, The University of Chicago Press, Chicago, 1965, p. 171; Flathman, R., Thomas Hobbes, Rowan \& Littlefield Publishers, Oxford, 2002.

21. Mutual fear. Hobbes, T., Do cidadão, Ed. Martin Claret, São Paulo, 2004, pp. 32-38.

22. Driven by the mechanics of passion. Cf: Strauss, L., Cropsey, J., History of political philosophy, The University of Chicago press, Chicago, 1987.

23. Regarding a possible new taxonomy of emotions based on the distinction between implosive and explosive emotions: Is fear an implosive emotion? 
but also an insight into the mind of the elected President and how he likes playing with fire. ${ }^{24}$ Let us take a look at some of the most relevant examples:

\section{Example 1: fear of crime}

a1) "Drugs are pouring across the border" or "Bad people are flooding through our airports."

This uses the rhetorical mechanism of exaggeration or amplification. But also always behind the amplifying discourse is the need to subtly instill a feeling of panic and, at the same time, plant the feeling that there is need of a savior;

a2) "We need to build a wall (quickly) and Mexico is paying" or "Nobody builds walls better than me, believe me."

Against the fear of invasion, the installation of the hero complex sets in and presents the solution: the big wall of America. Beyond the egocentric narcissist's obvious hidden desire for immortality and its multiple derivations, the wall has always been a very powerful collective symbol for patrimony.

Referring to a medieval or imperial imaginary past, full of soldiers with bows ready to defend the castle, it also conveys an obvious humor associated with the ridiculous and, in a move of reductio ad absurdum, simultaneously reveals the preposterous proposals as part of an infantile horizon where all is plain and not complex. In fact, it offers pseudo-solutions for pseudo-problems. But the appeal of simplicity saves time and rouses massive audiences. It's easy to see. And it's also easy to obliterate intellectual honesty, run over conventions and reinterpret reality by force. In that case, one might ask if argumentative fallacies can be funny. Is there an illogical thinking in humor? Is it just an exercise in perversion of the natural logic? Does Humor make use of irrationality? Or does it lack emotionality?

\section{Example 2: fear of terrorism}

The proposal for a temporary ban on Muslim immigration to the United States is a clear revival of or reconnection with the vast trauma of $9 / 11$. Never clear on the argument, but curiously always referring to the 'European situation', we can observe the same massive attack on big problems with simple solutions. The difference here is that in this case the association with immigration is obvious. The problematic bottleneck effect or the scape-goat logic is not here a specific emotion, but a manipulation (of the emotion) that makes full use of the constitutive desire for the security of the human (fear-security dialectic). The physical wall and the virtual wall are part of a movement that mobilizes the image of an imperial setting, with its ancient dichotomy between the civilized world and barbaric invaders. ${ }^{25}$

24. Cf Quo Vadis, 1955, Dir: Mervyn LeRoy; There is a fascinating and hypnotic power in fire : www.youtube.co $\mathrm{m} /$ watch? $=$ =EVVZwTMmk8c

25. Waiting for the Barbarians", Constantine Cavafy. 


\section{Example 3: anti-fear}

The final Trump argument is that he is courageous. The implied argument is: relax, I will solve all of this mess and you can be safe again or great again. ${ }^{26}$ The hero-coward dilemma could be interpreted through a hypothetical political psychopathology: first of all, narcissism involves a fear of disappearance, where the starving ego is dependent on the other's recognition, and second, this hunger pushes the action towards the need for focusing all the continuous attention. ${ }^{27}$

Trump's intended pharresia presents itself as a fight against political correctness, ${ }^{28}$ and this is doubly a winning strategy: on one side it targets the weary voter, attacking and discrediting opponents, and on the other hand, uses a victimization strategy where he accuses the media of vilifying him. This passive-aggressive positioning presents simultaneously the fierce attack ${ }^{29}$ of icy humor and the media victim, i.e., the lonely hero that resonates deeply with a part of the American culture, evoking its epic and heroic matrix.

The final joke on fear and argumentation would be that the candidate Hillary Clinton, from a certain point in her campaign, also started to use fear as an advantage in convincing undecided voters: the fear of Trump.

\section{Example 4: fear and funny business, i.e., politics}

This part of our inquiry could end with a set of remarks regarding the relation between fear and humor in general terms. Is fear in itself funny? Why is fear funny? Is it a mixture of ridicule and the absurd, or just a Freudian response as an escape mechanism? The relief comes from distance, a confortable distance, but one cannot forget the dilemma of ignorance and stupidity. ${ }^{30}$ I could, briefly and by way of synthesizing the argument, add that fear in comedy, or in humor in general, is operating under the placebo effect: no consequences, safe environment, implying a distance that corresponds to the sofa paradigm. Can fear be funny? Yes, on that thin line between light-heartedness (funny, while maintaining some connection) and distance (funny at a distance) - just as Chaplin or Keaton never get hurt even in the most extreme situations. The funniness is in the thrill, the unconscious-safe rush. The more complex question is: where does it stops being funny, in other words, could we distinguish comedy from tragedy? If so, on what terms? In the US election campaign the tragi-comic element was decisive: the supposed seriousness of political standards being threatened, and eventually succumbing to the natural spontaneity of the sharp humor of the Jester-King. The key element that can operate the shift in the perception of humor is when distance is annihilated by the nearness of the binominal potential-actual.

\footnotetext{
26. Strangely enough, a sort of implicit confession of the decadence of the USA.

27. It is a cause-effect located on a continuum that includes, and explains - for example - the torrent of Tweets.

28. Homer Simpson paradigm: it's funny because it's true?

29. Meyer, J., Humor as a Double-Edged Sword: Four Functions of Humor, Communication Theory,nº 10, August 2000.

30. In view of the impossibility of showing all the extensive contours of this problematic, I will merely suggest here that if a possible Stupidity Theory regarding Humor could be constructed, the following may provide some guidelines for possible research and investigation material:

. Cf : "On Bullshit"Harry G. Frankfurt, Robert Musil OnStupidity, Carlo Cipolla The basic laws of human stupidity, etc.
} 


\section{GENERAL CONSIDERATIONS ON DARK HUMOR}

The rise in negative political humor could be classified as dark humor or a one-man show that uses contempt and bets on roasting the adversaries tethered to political correctness and on these, dizzy against the ropes, failing to understand how to come back into the game that is now different from the usual campaign circus routine. There is a new circus in town, there is a new sheriff in town with a Schopenhaurian flavor mastering the art of insult. In other words, it's a natural resource contained in the reasonable doubt principle, imported from the judiciary system into the political arena. This appears simple and, in fact, the inception strategy relies on mass communication of one simple idea. It's political stand-up comedy at its highest peak. Unfortunately, not everyone appreciates the humor of candidate Trump. And those who don't see or who fail to understand this sort of acidic humor also fail to grasp humor as a martial art. The art of war requires practice and perfection of blows and strategy. It's the art of dealing with caustic humor and the practice of sharp irony in understanding politics as a blood-sport. ${ }^{31}$ Of course, candidate Donald Trump probably understood the medium prior to the game itself. But wouldn't that be a predictable advantage for a gladiator in ancient Rome? It suggests an understanding of the complex machine of political marketing and communication, which sees the president as a product and voters as consumers, of the new twists and turns of data analysis, segmentation of the audience, specific targeting, big data, small connections, cyberpolitics, cyberwar. This really means: massive attack, psy-ops, psywarfare applied in elections by the money factor, trying to overcome its adversaries by mastering the magic via the predictable world of political calculus. Foreseeing behavior and having that magic ball reinforces the self-prophesy syndrome over reality, guessing what people really want. The power of the silent majority is well-known. It is no easy task to understand all the nuances and variables that influenced this election. Maybe candidate Trump only surfed an upcoming wave, benefiting from the reaction of a large part of society that felt its citizenship ignored and politics to be no means to no end. My hypothesis is that the easy-going humor, the ironic attacks by candidate Trump, were decisive for his victory. Some say that this campaign was the final evidence that humor has no power over life because there is no politician in memory was as mocked as Trump was. The only problem with this argument is that it fails to see two things: firstly, that there is no bad publicity ${ }^{32}$ for the candidate Trump, only more space in the media, and secondly, even if the humor of the candidate wasn't that advanced, it certainly was effective. It is precisely that effectiveness that most commentators fail to see or simply won't recognize in him. It was quite visibly the comfortable expansion of the Trump campaign, in its warmongering and bullying syndrome, relying on the thirst for blood in its narcissistic vanity. The self-confidence was evident because it was relying on vertigo towards the abyss in the Trump negative campaign: just pathos, no ethos? The dark side of humor in this negative uprising reveals that sometimes the best

31. Especially clear in the debate with Hillary Clinton where she quotes Michellhe Obama on the low blows.

32. The candidate Trump was always in a win-win situation. If he won the Presidency - fine (I suspect that perhaps he didn't really expect that) but if he lost he would immediately become the most famous business man alive (he is this already). This political campaign was really about fame. In the past it was about credibility. The candidate Trump would never lose this election process because it was the most brilliant advertisement campaign ever made. Mad men or Vanity fair? Maybe a new book will emerge on Trump or how to fight your way to the top. Or just how to consolidate your own branding, confusing familiarity with credibility (making full use of the social capital recognition process). 
defense is offense. ${ }^{33}$ Candidate Trump had against the establishment the advantage of an image of the "outsider", i.e., non-politician, implying non-deceitful. This is not only political discourse analysis, but a cross-strategy of spontaneity (that could be confused with authenticity) and courage (that could be confused with the impulsiveness of saying what's in one's mind). But also humor. A sort of deductive procedure in Trump's humor relies on the superiority theory, supported by easy politics from populism to demagogy. ${ }^{34}$ Let's now turn our focus on three examples that constitute an informal logic of the affects exhibiting the central device/mechanism of the Trump's candidacy campaign:

ABSURD (ridicule) $>$ SURPRISE > HUMOR.

I will demonstrate my hypothesis in a deductive form through specific examples:

\section{Example 1: The People Vs. The Politicians (Candidate Trump Vs. The World)}

The most general of the terms in the syllogism for Trump's victory is the construction of the lone crusader against the evil of Politics. On behalf of the forgotten Americans the candidate promisses to fight the power and drain the rigged swamp. The attack on political correctness and establishment constitutes itself in different levels. The most recurrent and systematic plan is the attack on politicians and politics as places of non-solution, proposing a general position that many call anti-system, or even populism, in the call for emotional voting. The non-political-pop-iconbusiness-tv-star, in seeking the ad populum argument, invites laughter by provoking surprise and disbelief, through questioning Politics itself. The others have failed where he will succeed. The non-politician running for a political institution is immune to contradiction. The candidate is in a special category. He alone will restore safety and greatness to America. Again.

\section{Example 2: The Puppet (show) Master (Candidate Trump Vs The Republicans)}

In the search for a Republican candidate, the number of situations and targets are innumerable. ${ }^{35}$ This will be a general formula applying throughout the whole run for Presidency, but the tuning sets in during the Republican candidate selection. It's a basic humor schema that relates to childhood, recalling games of imitation. The resource to mimicry of the opponent tends to ridicule and diminish her/his credibility through caricature. Physical humor is very effective because it's simple and everybody gets it. Of course, the travesty aims to install a game between the rational and the emotional, promoting a process of maximum differentiation. In this constructive space of ridicule, we can observe the use of humor as an ethical quasi-argument that is also an argument of contempt (inferiority / superiority). The oscillation and variation of scales, of particular and general, in this mixed model, allows the candidate a strongly charismatic duplicity in a strategy of harsh scorn and piety, mixing ad hominem attacks and ad misericordiam arguments of defense against the media.

33. The continuous attack mode in a consistent form quickly transformed a negative campaign into an ugly one. But is it just the Trump upgrade? In order for this to be clear, a historical comparative map would be needed, placing it alongside all the previous elections. Since there is no space in this article to do that, let's just propose that exercise.

34. "Demagogy is the worst of lies, it's a lying lie", Tim Maia.

35. Cf. www.youtube.com/watch?v=Bj3QFBX9P_c, etc. 


\section{Example 3: Final Round: fight. (Candidate D. Trump Vs Candidate H. Clinton)}

Politics as a blood-sport places us in the boxing match. The political performance of the candidate Trump was ambivalent in its use of humor on the one hand, but also in its dramatic entries regarding health, professional ethics, and legal situation of the opponent, to name just a few. Our central point here is that humor is a weapon of mass destruction. The candidate Clinton was an absolute target as a scape-goat, but also as a focal point for ridicule. Why? Because it allows a shift in the scale of perception and emotion (the maximum emotion sought as effect is that of contempt, which promotes estrangement), as a process of untying, in the following schematic structure:

EMOTION $>$ (reasonableness) $>$ PERCEPTION $>$ (rationality) $>$ ACTION.

This strategy of humor in its reduction to an absurd minimum occurs many times and particularly with reference to caricature, which promotes a condensing reduction to a particular amplified characteristic, in order to characterize the other. This simplification facilitates the elaboration of judgments of value, since the caricature as a miniaturizing process accomplishes the fixation of a simple image which is glued to the target, and is a key factor at the level of memory-formation which ensues, coalescing the image. It thence impacts the decision-making process. Generally, this type of humorous strategy in argumentation fits the general category of ad hominem, that is, the clear personal attack as an objective of schematics that could be synthesized in the simple premise that $x$ has no character, so the argument of $x$ should not be accepted. In this sense, caricature can be considered simultaneously as political argument, as a weapon (defensive and/or offensive), and aesthetically as caricatured (foregrounding inability/deformity) image. Of course, humor as play is also a battle game between emotional intelligences, and if play is generally a signal of non-aggression, it could also be perceived as chess-game combat.

In conclusion, the fallacious deductive demolition system could be summed up in the following argument:

Politicians are no good,

Republicans candidates are no good,

Hillary is no good,

I'm not a politician. I'm the best.

The premises and conclusion of the perfect inception system in contemporary media-driven democratic societies, where time is a luxury, are: simple ideas, simple solutions. So, besides all the fun, the laughs, the dark humor, what could go wrong? Let's remember Kierkegaard, and end with a killing joke:

"A fire broke out backstage in a theatre. The clown came out to warn the public; they thought it was a joke and applauded. He repeated it; the acclaim was even greater. I think that's just how the world will come to an end: to general applause from wits who believe it's a joke"; ${ }^{36}$ or, in the words of Woody Allen: never trust a naked bus driver.

36. Kierkegaard, S, Either/Or, , Princeton University Press, Princeton, 1987. 


\section{BIBLIOGRAPHY}

Ben-Ze'ev, A. (2000). The Subtlety of Emotions. Ed. Massachusetts Institute of Technology.

Borchers,T. (1998). The Burlesque, the Comic, and the Tragic, Paper presented to the National Communication Association, 1998 Convention, New York,Nov. 22.

Kasper, K. (2013). O jogo dos Clowns. Revista Nada, (17).

Král, P. (s.d.). Le Burlesque. Éditions Ramsay, of California Press.

Manstead, A.; Frijda, N. \& Fischer, A. (ed.) (2004). Feelings and Emotions. Cambridge University Press.

Moore, M. P. (1992). The Quayle Quagmire: Political Campaigns in the Poetic Form of Burlesque. Western Journal of Communication, 56, Spring: 108-124.

Meyer, J. (2000). Humor as a Double-Edged Sword: Four Functions of Humor. Communication Theory (10), August.

Rorty, A. (ed.) (1980). Explaining emotions. University of California Press.

Solomon, R. (ed.) (2003). What is an emotion?. Oxford University Press.

Smith, C.; \& Voth, B. (2002). The Role of Humor in Political Argument: How 'strategery' and 'lockboxes' Changed a Political Campaign.

Strauss., L. (1965). Natural right and history. The university of chicago press, Chicago.

Flathman, R. (2002). Thomas Hobbes. Oxford: Rowan \& Littlefield Publishers.

Hobbes, T. (2004). Do cidadão. São Paulo: Ed. Martin Claret.

Strauss, L. \& Cropsey, J. (1987). History of political philosophy. Chicago: The university of chicago press. 